\title{
Technical cashew nut shell liquid associated with non-protein nitrogen sources in high-grain diets for ruminants: intake and digestibility of nutrients, ruminal fermentation, and microbial protein synthesis
}

\section{Líquido da castanha de caju técnico associado a fontes de nitrogênio não proteico em dietas alto grão para ruminantes: consumo e digestibilidade de nutrientes, fermentação ruminal e síntese de proteína microbiana}

\author{
Milene Puntel Osmari ${ }^{1 *}$; Antonio Ferriani Branco²; Tatiana Garcia Diaz²; \\ Laiz Fiorilli de Matos ${ }^{3}$; Rafael Henrique de Tonissi e Buschinelli de Goes"; \\ Ana Lúcia Teodoro ${ }^{5}$
}

\begin{abstract}
This study aimed to evaluate the association of technical cashew nut shell liquid (tCNSL) and two sources of non-protein nitrogen (NPN), dry matter intake (DMI), the partial and total apparent digestibility coefficient of nutrients, ruminal fermentation, microbial synthesis, and blood characteristics. Four Holstein steers $(438 \mathrm{~kg} \pm 17.14 \mathrm{~kg})$ fitted with ruminal and duodenal cannula were used. Diets had (in DM basis) $135 \mathrm{~g} \mathrm{~kg}^{-1}$ of crude protein and $746 \mathrm{~g} \mathrm{~kg}^{-1}$ of total digestive nutrients. The roughage to concentrate ratio was 30:70. The experimental design was a 4 x 4 Latin square with 14-day experimental periods. The non-protein nitrogen sources used were livestock urea (U) and slow-release urea (SRU) (Optigen ${ }^{\circledR}$ II). The treatments consisted of diets containing $\mathrm{U}$ or SRU associated or not with tCNSL. The tCNSL was added to the diet in a proportion of $300 \mathrm{mg} \mathrm{kg}^{-1}$ of concentrate. DMI and ruminal, intestinal and total apparent digestibility coefficients of nutrients were not affected by experimental diets. The association of sources of NPN and tCNSL did not affect $\mathrm{pH}$, ammoniacal nitrogen $\left(\mathrm{NH}_{3}-\mathrm{N}\right)$, plasma urea nitrogen (PUN), and microbial synthesis of animals consuming high-grain diets.
\end{abstract}

Key words: Additives. Bovines. Nitrogen. Urea.

\section{Resumo}

Objetivou-se avaliar a associação do líquido da casca da castanha de caju técnico (tLCC) e duas fontes de nitrogênio não proteico (NNP), sobre a ingestão de matéria seca (IMS), coeficiente de digestibilidade

${ }^{1}$ Dr $^{\mathrm{a}}$ em Zootecnia, Prof ${ }^{\mathrm{a}}$, Universidade Federal de Santa Catarina, UFSC, Florianópolis, SC, Brasil. E-mail: mileneosmari@ yahoo.com.br

2 Drs. em Zootecnia, Departamento de Zootecnia, Universidade Estadual de Maringá, UEM, Maringá, PR, Brasil. E-mail: afbranco7757@gmail.com; tatianagarcia.diaz@gmail.com

3 M.e em Zootecnia, Departamento de Zootecnia, UEM, Maringá, PR, Brasil. E-mail: laiz.fiorilli@hotmail.com

4 Dr. em Zootecnia, Universidade Federal da Grande Dourados, UFGD, Dourados, MS, Brasil. E-mail: rafaelgoes@ufgd.edu.br

5 Dr $^{\mathrm{a}}$ em Zootecnia, Prof ${ }^{\mathrm{a}}$, Instituto Federal de Educação, Ciência e Tecnologia do Piaú, IFPI, Teresina, PI, Brasil. E-mail: analuciazoo@yahoo.com.br

* Author for correspondence 
aparente parcial e total dos nutrientes, parâmetros de fermentação ruminal, síntese de proteína microbiana no rúmen e nitrogênio ureico plasmático (NUP) de bovinos confinados. Foram utilizados quatro novilhos da raça Holandesa $(438 \mathrm{~kg} \pm 17,14)$, providos de cânula ruminal e duodenal. As dietas continham (em base na MS) $135 \mathrm{~g} \mathrm{~kg}^{-1}$ de proteína bruta e $746 \mathrm{~g} \mathrm{~kg}^{-1}$ de nutrientes digestivos totais em uma relação volumoso:concentrado de 30:70. O delineamento experimental utilizado foi o quadrado latino 4 x 4, com períodos experimentais de 14 dias. As fontes de NNP foram ureia pecuária (U) e ureia de liberação lenta (ULL) (Optigen®II). Os tratamentos consistiram em dietas contendo U ou ULL associados ou não ao tLCC. O tLCC foi incluído no concentrado objetivando-se uma concentração final na dieta de $300 \mathrm{mg} \mathrm{kg}^{-1}$. A IMS e os coeficientes de digestibilidade aparente ruminal, intestinal e total dos nutrientes não foram influenciados pelos aditivos, bem como o $\mathrm{pH}$, nitrogênio amoniacal, NUP e eficiência de síntese microbiana ruminal dos animais consumindo dietas alto grão.

Palavras-chave: Aditivo. Bovinos. Nitrogênio. Ureia.

\section{Introduction}

The intensification of animal production systems has led to changes in the profile of the supplied diets since they became high proportion of concentrate rather than the high proportion of roughage, especially in cattle production, increasing the productivity by area.

In this process, the increase in the availability of non-structural carbohydrates and the consequent decreases in $\mathrm{pH}$ values cause intense modifications in the ruminal environment. Among these modifications is the reduction in the population of cellulolytic microorganisms, with a reduction in the structural carbohydrate degradation and increase in the amylolytic population, which produces lactate and can cause ruminal acidosis (VAN SOEST, 1994).

In animal production systems, antibiotics are used to preventing diseases and metabolic disorders, as well as improving food efficiency, acting as growth promoters. Recently, the public concern about its use has increased, which resulted in a ban on the use of these components in the animal feed (PUREVJAV et al., 2013).

Thus, substances that can replace antibiotics should be evaluated. The functional oils appear with great possibilities since they act in the improvement of fermentation efficiency in the ruminal, decreasing methane production and nutritional stress, as well as improving animal health and productivity (SHINKAI et al., 2012; BAYAT et al., 2018).

In this context, technical cashew nut shell liquid (tCNSL) is pointed as one of the feed additives able to comply with these requirements (BRANCO et al., 2015). However, information on the responses of this product to animal nutrition is scarce and deserves to be evaluated.

Dietary urea is rapidly hydrolyzed in the rumen, resulting in a rumen ammonia peak within the first few hours after feed intake. However, the ruminal degradation of carbohydrates and microbial growth is a much slower process. The higher synchrony between these processes can improve the efficiency of use of non-protein nitrogen (NPN) (TAYLOR-EDWARDS et al., 2009). Thus, the use of slow-release urea (SRU) may meet this need (BOURG et al., 2012), as it may provide a reduction in the rumen deamination process, decreasing ammoniacal nitrogen concentrations and making its concentrations more uniform during the day, favoring the efficiency of microbial protein production.

The aim of this study was to evaluate the effect of the use of technical cashew nut shell liquid associated with two sources of non-protein nitrogen on partial and total apparent digestibility of nutrients and ruminal fermentation parameters of cattle fed high-grain diets. 


\section{Material and Methods}

The experiment was carried out in the Feed Evaluation Facilities for Ruminant Animals of the Experimental Farm of Iguatemi and in the Laboratory of Analysis of Feed and Animal Nutrition, belonging to the State University of Maringá (UEM), Maringá, Paraná State, Brazil.

Four Holstein steers weighing, on average, 348 $\pm 17.14 \mathrm{~kg}$ and with rumen and duodenal cannula were used. The experimental design was a 4 x 4 Latin square, with 14-day periods and the last 3 days for sampling. The animals were housed in individuals and covered stalls $\left(8.75 \mathrm{~m}^{2}\right)$ equipped with an individual feeder and automatic drinking troughs. All procedures performed with the animals are in accordance with the Law 11794 of October 8, 2008, Decree 6899 of July 15, 2009, as well as the rules issued by the National Council for the Control of Animal Experimentation (CONCEA). Furthermore, they were carried out in accordance with the standards of ethical criteria approved by the Ethics and Biosafety Committee (CEUA 023/2015).

The diets consisted of $300 \mathrm{~g} \mathrm{~kg}^{-1}$ of corn silage and $700 \mathrm{~g} \mathrm{~kg}^{-1}$ of concentrate, based on dry matter (DM), made from ground corn, wheat bran, minerals, urea/Optigen $\mathrm{II}^{\circledR}$, and technical cashew nut shell liquid (tCNSL) (Table 1).

Table 1. Chemical composition ( $\left.\mathrm{g} \cdot \mathrm{kg}^{-1}\right)$ of feeds and high-grain experimental diets $\left(\mathrm{g}^{\mathrm{kg}} \mathrm{kg}^{-1}\right)\left(700 \mathrm{~g} \mathrm{~kg}^{-1}\right.$ of concentrate) with two non-protein nitrogen (NPN) sources associated or not with technical cashew nut shell liquid (tCNSL).

\begin{tabular}{|c|c|c|c|c|c|c|c|c|c|c|}
\hline \multirow{2}{*}{\multicolumn{2}{|c|}{ Feeds }} & \multirow{2}{*}{$\mathrm{DM}^{1}$} & \multirow{2}{*}{$\mathrm{CP}$} & \multirow{2}{*}{$\mathrm{EE}$} & \multirow{2}{*}{ Ash } & \multirow{2}{*}{ NDF } & \multirow{2}{*}{$\mathrm{ADF}$} & \multirow{2}{*}{ Starch } & \multicolumn{2}{|c|}{ Diets* } \\
\hline & & & & & & & & & $\mathrm{U}$ & SRU \\
\hline \multicolumn{2}{|l|}{ Corn silage } & 303 & 70 & 30 & 39 & 504 & 225 & 212 & 300 & 300 \\
\hline \multicolumn{2}{|c|}{ Ground corn } & 920 & 87 & 42 & 14 & 87 & 32 & 594 & 467 & 465 \\
\hline \multicolumn{2}{|c|}{ Wheat bran } & 924 & 180 & 29 & 35 & 283 & 81 & 369 & 196 & 196 \\
\hline \multicolumn{2}{|l|}{ Urea } & 990 & 2810 & - & - & - & - & - & 15 & - \\
\hline \multicolumn{2}{|l|}{ Optigen ${ }^{\circledR} I I$} & 990 & 2560 & - & - & - & - & - & - & 17 \\
\hline \multicolumn{2}{|l|}{ Minerals } & 990 & - & - & 990 & - & - & - & 22 & 22 \\
\hline \multicolumn{11}{|c|}{ Chemical composition of experimental diets $\left(\mathrm{g} \mathrm{kg}^{-1}\right)$} \\
\hline Diets* & $\mathrm{DM}$ & $\mathrm{CP}$ & $\mathrm{EE}$ & Ash & \multicolumn{2}{|c|}{ NDF } & $\mathrm{NFC}^{2}$ & Starch & \multicolumn{2}{|c|}{$\mathrm{TDN}^{2}$} \\
\hline $\mathrm{U}$ & 923 & 135 & 34 & 47 & \multicolumn{2}{|r|}{252} & 535 & 420 & \multicolumn{2}{|c|}{747} \\
\hline SRU & 923 & 135 & 34 & 47 & \multicolumn{2}{|r|}{252} & 535 & 419 & \multicolumn{2}{|c|}{746} \\
\hline
\end{tabular}

*Diets: U - diet with urea; SRU - diet with slow release urea (Optigen $\left.{ }^{\circledR} I I\right)$. Diets in DM basis. Technical cashew nut shell liquid (tCNSL) was added in percentage of concentrate, to a final concentration of $300 \mathrm{mg} \mathrm{kg}^{-1}$ of concentrate. ${ }^{1} \mathrm{DM}$ - dry matter; CP crude protein; EE - ether extract; NDF - neutral detergent fiber; ADF - acid detergent fiber. ${ }^{2}$ Non-fibrous carbohydrates and total digestible nutrients, respectively, calculated by NRC (2001).

The tCNSL was associated with different sources of NPN, as follows: $\mathrm{U}+\mathrm{tCNSL}=$ urea with technical cashew nut shell liquid; U - tCNSL $=$ urea without technical cashew nut shell liquid; $\mathrm{O}$ $+\mathrm{tCNSL}=$ Optigen $\mathrm{II}^{\circledR}$ with technical cashew nut shell liquid; and $\mathrm{O}-\mathrm{tCNSL}=$ Optigen $\mathrm{II}^{\circledR}$ without technical cashew nut shell liquid.
The tCNSL composition (Usibras-Aquiraz, Ceará State, Brazil) was $73.3 \%$ of cardanol, $16.4 \%$ of cardol, and $3.0 \%$ of methylcardol, being determined by gas chromatography on the Shimadzu GCMS-QP2010 Ultra System apparatus equipped with AOC-20i auto-injector. The column used was a Restek RTX-5ms (30 m, $0.25 \mathrm{~mm}$ 
i.d., $0.25 \mu \mathrm{m}$ df), coated with $5 \%$ diphenyl-95\% polydimethylsiloxane, operated with the following temperature program: $50{ }^{\circ} \mathrm{C}$ with increasing of 10 ${ }^{\circ} \mathrm{C} \mathrm{min}{ }^{-1}$ to $200{ }^{\circ} \mathrm{C}$; increasing $2{ }^{\circ} \mathrm{C} \mathrm{min}^{-1}$ to $320^{\circ} \mathrm{C}$; injection temperature and volume: $250{ }^{\circ} \mathrm{C}$ and 1.0 $\mu \mathrm{L}$, respectively; injection mode: splitless and drag gas: helium at $300{ }^{\circ} \mathrm{C}$, as described by Coutinho et al. (2014).

The animals were fed as a total mixed ration, ad libitum, twice a day (08h00 and 16h00) and tCNSL was added during concentrate preparation, objectifying an intake of $300 \mathrm{mg}$ tCNSL kg-1 of concentrate. Animal feed intake was determined considering the supply and the orts, which were collected and weighed daily before the first meal. To determine the ruminal, intestinal, and total digestibility of dry matter (DM), organic matter $(\mathrm{OM})$, crude protein $(\mathrm{CP})$, ethereal extract (EE), neutral detergent fiber corrected for ash and protein (NDFc), and non-fibrous carbohydrate (NFC), samples of duodenal digesta $(\sim 300 \mathrm{~mL})$ were collected through a duodenal cannula and feces directly into the rectal orifice. For the determination of duodenal flow and fecal production, all animals received a daily dose of $10 \mathrm{~g}$ of titanium dioxide $\left(\mathrm{TiO}_{2}\right)$ directly in the rumen from the second day of each experimental period (FERREIRA et al., 2009).

Duodenal digesta and fecal samples were taken from the $11^{\text {th }}$ day for three days at alternate times, as follows: $0,2,4,6,8,10,12,14,16,18$, and 20 hours after the first feeding. The samples of duodenal digesta and feces were packed identified in plastic bags and frozen at $-20{ }^{\circ} \mathrm{C}$. Subsequently, the samples were thawed, pre-dried in a forced air circulation oven at $55^{\circ} \mathrm{C}$ for 72 hours, and ground in a $1 \mathrm{~mm}$ sieve Willey mills. The samples were then mixed based on the percentage of dry weight and formed a composite sample of duodenal digesta and feces per diet/period.

Samples of the supplied feed, orts, duodenal digesta, and feces were analyzed by determining the dry matter (DM) (method \#934.01); organic matter (OM), according to ashes (method \#924,05: $\mathrm{OM}=100$ - ashes); crude protein (CP), obtained by determination of the total $\mathrm{N}$ by the Kjeldahl microtechnique (method \#920.87 N x 6.25); ethereal extract (EE), determined gravimetrically after extraction using petroleum ether in a Soxhlet apparatus (AOAC, 1990); and neutral detergent fiber corrected for ash and protein $(\mathrm{NDFc})$, according to Van Soest et al. (1991) using the TE-149 fiber analyzer (Tecnal Equipment for Laboratory Inc., Piracicaba, Brazil). The percentage of total digestible nutrients (TDN) was calculated according to the equation described by Sniffen et al. (1992): $\mathrm{TDN}=\mathrm{DCP}+\mathrm{DNDF}+\mathrm{DNFC}+(\mathrm{DEE} \times 2.25)$. Where: $\mathrm{TDN}=$ total digestible nutrients $\left(\mathrm{g} \mathrm{kg}^{-1}\right)$; $\mathrm{DCP}=$ digestible crude protein $\left(\mathrm{g} \mathrm{kg}^{-1}\right) ; \mathrm{DNDF}=$ digestible neutral detergent fiber $\left(\mathrm{g} \mathrm{kg}^{-1}\right)$; DNFC $=$ digestible non-fibrous carbohydrates $\left(\mathrm{g} \mathrm{kg}^{-1}\right)$; DEE $=$ digestible ethereal extract $\left(\mathrm{g} \mathrm{kg}^{-1}\right)$.

The non-fibrous carbohydrates (NFC) were calculated according to NRC (2001): NFC ( $\left.\mathrm{g} \mathrm{kg}^{-1}\right)$ $=100-\left(\left(\mathrm{g} \mathrm{kg}^{-1}\right) \mathrm{CP}+\left(\mathrm{g} \mathrm{kg}^{-1}\right) \mathrm{NDFc}+\left(\mathrm{g} \mathrm{kg}^{-1}\right) \mathrm{EE}+\right.$ $\left.\left(\mathrm{g} \mathrm{kg}^{-1}\right) \mathrm{Ash}\right)$. The samples of duodenal digesta and feces were analyzed for determining the titanium concentration according to Myers et al. (2004).

For starch determination through the acid method (IAL, 2008), approximately $30 \mathrm{~g}$ of feed samples, orts, duodenal digesta, and feces were sent to the Laboratory of Physical and Chemical Analysis of the ABC Foundation in Castro, Paraná State, Brazil.

The CP contents of feces determined during the chemical analyses were considered for fecal $\mathrm{N}$ determination $\left(\mathrm{g} \mathrm{day}^{-1}\right)$, with $\mathrm{CP}$ value divided by 6.25. However, urinary $\mathrm{N}\left(\mathrm{g} \mathrm{d}^{-1}\right)$ was estimated by the following equation proposed by Waldrip et al. (2013): Urinary $\mathrm{N}\left(\mathrm{g} \mathrm{d}^{-1}\right)=0.56 *(\mathrm{~N}$ ingested $(\mathrm{g}$ $\left.\left.\mathrm{d}^{-1}\right)\right)-21.18$.

Between the $11^{\text {th }}$ and $13^{\text {th }}$ day of each experimental period, $150 \mathrm{~mL}$ of rumen fluid were sampled via ruminal cannula to determine $\mathrm{pH}$ and $\mathrm{N}-\mathrm{NH}_{3}$ concentration. The first collection was taken immediately before the first feeding of the day (time 
0 ) and the others at 2, 4, 6, and 8 hours after the first feeding. After each collection of rumen fluid, the $\mathrm{pH}$ was immediately measured with a digital $\mathrm{pH}$ meter (Digimed DM20 - Digimed Instrumentação Analítica, Campo Grande, São Paulo State, Brazil).

For the ammoniacal nitrogen $\left(\mathrm{N}-\mathrm{NH}_{3}\right)$ analysis, a $50 \mathrm{~mL}$ aliquot of rumen fluid was acidified $(0.5$ $\mathrm{mol} / \mathrm{L} \mathrm{H}_{2} \mathrm{SO}_{4}$ ) and stored at $-20{ }^{\circ} \mathrm{C}$ for further analysis. At the end of the experiment, the rumen fluid was thawed at ambient temperature and centrifuged at $3,000 \times \mathrm{g}$ for $15 \mathrm{~min}$. The $\mathrm{N}_{-} \mathrm{NH}_{3}$ concentration of samples was determined by the Fenner (1965) method.

On the $7^{\text {th }}$ and $14^{\text {th }}$ experimental days of each period, blood samples were collected in tubes of vacutainer, with the addition of anticoagulant, by means of puncture of the jugular vein. To obtain the plasma, the samples were centrifuged at 2,500 $\mathrm{x} g$ for $15 \mathrm{~min}$ at $4{ }^{\circ} \mathrm{C}$. The concentration of urea was determined in the plasma by the modified diacetyl method (GoldAnalisa ${ }^{\circledR}$ ) and plasma urea nitrogen (PUN) was obtained by multiplying the urea concentration by the corresponding value of $\mathrm{N}$ content in the urea (0.466).

For the microbial synthesis efficiency, on the $13^{\text {th }}$ day of each experimental period, four hours after the second feeding and on the $14^{\text {th }}$ day before the first feeding, $1.5 \mathrm{~kg}$ of ruminal content of each animal were collected and mixed with $500 \mathrm{~mL}$ of saline solution $\left(9 \mathrm{~g} \mathrm{NaCl} \mathrm{L}^{-1}\right)$, being homogenized for $1 \mathrm{~min}$ in a blender and filtered in cheesecloths. After this procedure, the samples were frozen at -20 ${ }^{\circ} \mathrm{C}$. At the end of the experiment, the samples were thawed and the bacteria were isolated by differential centrifugation (500 $\mathrm{x} g$ and 27,000 $\mathrm{x} g$ ) according to the procedures described by Cecava et al. (1990). After the last sample centrifugation with distilled water, a further centrifugation was also carried out with distilled water, aiming to decrease the saline content in the samples and possible contaminations with salt. The bacterial pellets resulting from the centrifugations were dried at $55{ }^{\circ} \mathrm{C}$ for 48 hours and macerated for determining the total DM, total $\mathrm{N}$, total purines, and microbial synthesis efficiency according to Ushida et al. (1985).

The experimental design was a $4 \times 4$ Latin square. The data were interpreted by an analysis of variance (ANOVA), followed by the analysis of orthogonal contrasts between diets. However, as there was no significant variation between the experimental diets according to the tested effects, they will not be discussed in this paper.

The procedure PROC MIXED of SAS (Statistical Analysis System, version 9.1) was used considering a $\alpha=0.05$ probability and the following mathematical model: $\mathrm{Y}_{\mathrm{ijk}}=\mu+\mathrm{A}_{\mathrm{i}}+\mathrm{P}_{\mathrm{j}}+\mathrm{T}_{\mathrm{k}}+\mathrm{e}_{\mathrm{ijk}}$. Where: $Y_{\mathrm{ijk}}=$ observed variable; $\mu=$ general mean; $\mathrm{A}_{\mathrm{i}}=$ effect of the animal $\mathrm{i}$ between 1 and $4 ; \mathrm{P}_{\mathrm{j}}=$ effect of the period $\mathrm{j}$ between 1 and $4 ; \mathrm{T}_{\mathrm{k}}=$ effect of the treatment $\mathrm{k}$ between 1 and $4 ; \mathrm{e}_{\mathrm{ijk}}=$ random error. All effects were considered fixed, except for the animal effect, which was considered random. For the ruminal fermentation data, the command REPETEAD from PROC MIXED was used once they are measured over time following the model: $Y_{i j}=\mu+D_{i}+t_{j}+D_{i}\left(t_{j}\right)+e_{i j}$; where: $\mu=$ general mean, $D_{i}=$ fixed dietary effect, $t_{j}=$ fixed effect of collection time $(0,2,4,6$, and 8$), \mathrm{D}_{\mathrm{i}}\left(\mathrm{t}_{\mathrm{j}}\right)=$ interaction, and $\mathrm{e}_{\mathrm{ij}}=$ error.

\section{Results and Discussions}

The intake of dry matter (DM) and other nutrients were not influenced by the experimental diets (Table 2). The average DM intake was $9 \mathrm{~kg}$ $\mathrm{d}^{-1}$, corresponding to $2.6 \mathrm{~g} \mathrm{~kg}^{-1}$ of the live weight (LW) and $110 \mathrm{~g} \mathrm{~kg} \mathrm{LW}^{-0.75}$, being considered a high intake.

With the high intake of a high-grain diet, in which $53.76 \%$ of the total DM intake was represented by non-fibrous carbohydrates (Table 2), metabolic disturbances such as acidosis were expected, but it was not verified. This behavior may be associated with the $25 \%$ NDF content of the diet (Table 1), 
which is the minimum amount necessary for a good ruminal functioning.

Production uniformity of by-products of $\mathrm{N}$ degradation present in slow-release NPN sources could favor the intake of supplements more rapidly when compared to supplements containing urea. However, this was not enough to favor an increase in intake ( $\mathrm{P}>0.05$; Table 2$)$ when the animals fed SRU, suggesting that although a high DM intake has occurred, the by-products of $\mathrm{N}$ degradation did not limit feed intake regardless of the used source.

Table 2. Intake of nutrients by cattle fed high-grain diets associated or not with technical cashew nut shell liquid (tCNSL) and two non-protein nitrogen (NPN) sources.

\begin{tabular}{|c|c|c|c|c|c|c|}
\hline \multirow{3}{*}{ Intake $^{1}$} & \multicolumn{4}{|c|}{ Diets $^{2}$} & \multirow{3}{*}{ SEM } & \multirow{3}{*}{$\mathrm{P}<$} \\
\hline & \multicolumn{2}{|c|}{ - tCNSL } & \multicolumn{2}{|c|}{$+\mathrm{tCNSL}$} & & \\
\hline & $\mathrm{U}$ & SRU & $\mathrm{U}$ & SRU & & \\
\hline $\mathrm{DM}\left(\mathrm{g} \mathrm{d}^{-1}\right)$ & 8761.48 & 9161.90 & 9225.83 & 8821.41 & 478.129 & 0.87 \\
\hline $\mathrm{DM}\left(\mathrm{g} \mathrm{kg}^{-1} \mathrm{LW}\right)$ & 2.52 & 2.62 & 2.64 & 2.56 & 0.095 & 0.82 \\
\hline $\mathrm{DM}\left(\mathrm{g} \mathrm{kg} \mathrm{LW}^{-0,75}\right)$ & 108.84 & 113.21 & 113.92 & 110.38 & 3.966 & 0.79 \\
\hline $\mathrm{CP}\left(\mathrm{g} \mathrm{d}^{-1}\right)$ & 1186.39 & 1251.32 & 1254.56 & 1202.73 & 69.997 & 0.87 \\
\hline $\mathrm{CP}\left(\mathrm{g} \mathrm{kg}^{-1} \mathrm{PV}\right)$ & 0.34 & 0.36 & 0.36 & 0.35 & 0.011 & 0.70 \\
\hline $\operatorname{NDF}\left(\mathrm{g} \mathrm{d}^{-1}\right)$ & 2172.05 & 2267.66 & 2279.26 & 2183.90 & 123.026 & 0.90 \\
\hline NDF $\left(\mathrm{g} \mathrm{kg}^{-1} \mathrm{LW}\right)$ & 0.63 & 0.65 & 0.65 & 0.63 & 0.031 & 0.91 \\
\hline $\mathrm{EE}\left(\mathrm{g} \mathrm{d}^{-1}\right)$ & 297.52 & 308.27 & 313.47 & 299.08 & 20.196 & 0.94 \\
\hline $\operatorname{Starch}\left(\mathrm{g} \mathrm{d}^{-1}\right)$ & 3705.92 & 3875.14 & 3904.60 & 3725.41 & 211.226 & 0.88 \\
\hline Starch $\left(\mathrm{g} \mathrm{kg}^{-1} \mathrm{LW}\right)$ & 1.07 & 1.11 & 1.12 & 1.08 & 0.041 & 0.83 \\
\hline $\mathrm{NFC}\left(\mathrm{g} \mathrm{d}^{-1}\right)$ & 4714.67 & 4927.54 & 4967.32 & 4742.65 & 259.704 & 0.87 \\
\hline $\mathrm{NFC}\left(\mathrm{g} \mathrm{kg}^{-1} \mathrm{LW}\right)$ & 1.36 & 1.41 & 1.42 & 1.38 & 0.050 & 0.81 \\
\hline TDN $\left(\mathrm{g} \mathrm{kg}^{-1}\right)^{1}$ & 750.00 & 745.30 & 741.00 & 743.90 & 1.456 & 0.98 \\
\hline
\end{tabular}

${ }^{1} \mathrm{DM}$ - dry matter; CP - crude protein; NDF - neutral detergent fiber; EE - ether extract; NFC - non-fibrous carbohydrate and TDN - total digestible nutrients. ${ }^{2}$-tCNSL - diet without technical cashew nut shell liquid (tCNSL); +tCNSL - diet with tCNSL; U - diet with urea; SRU - diet with slow release urea. SEM - standard error of mean, P - P value.

Considering an average intake of $9 \mathrm{~kg} \mathrm{DM} \mathrm{d}^{-1}$ (Table 2) of a diet composed by $710.3 \mathrm{~g} \mathrm{~kg}^{-1}$ of concentrate with $932 \mathrm{~g} \mathrm{~kg}^{-1} \mathrm{DM}$, the tCNSL intake associated with the supplement was approximately $2.06 \mathrm{~g} \mathrm{~d}^{-1}$. This amount can be considered satisfactory for the present research, although it did not provide changes in the evaluated variables. However, further studies need to be carried out.

Coutinho et al. (2014) found no change in DM intake when lactating dairy cows received increasing levels of tCNSL up to $0.036 \%$ of DM intake. Similarly, Branco et al. (2015) did not observe significant differences in DM intake when $30 \mathrm{~g} /$ animal/day of tCNSL was provided to lactating dairy cows, but with a decrease in methane production.

The ruminal, intestinal, and total digestibility coefficients of all nutrients were not influenced by the evaluated diets $(\mathrm{P}>0.05$; Tables 3$)$. Maeda et al. (2007) observed that a higher ruminal protein digestion, and a consequent disappearance of $\mathrm{N}$, may lead to a higher ammonia absorption by the rumen wall or a lower $\mathrm{N}$-fixing in the microbial $\mathrm{N}$ form, being desirable negative or close-to-zero ruminal digestibility values. However, this behavior was not observed in Table 2 since, on average, the 
animals had a ruminal digestibility coefficient of $\mathrm{CP}$ of $289 \mathrm{~g} \mathrm{~kg}^{-1}$ and the animals that fed SRU without the presence of tCNSL presented the lowest value for this variable $\left(258 \mathrm{~g} \mathrm{~kg}^{-1}\right)$.

Some sources of NPN and the use of tCNSL can stimulate microbial efficiency and thus improve
NDF digestibility according to Castañeda et al. (2009) and Branco et al. (2015), respectively. However, no effect of NPN sources was observed on the fiber digestibility (Table 3), but the average NDF intake of $24.73 \%$ of DM intake (Table 2) was sufficient to provide a high total apparent digestibility of DM (73.35\%; Table 3).

Table 3. Rumen (RDC), intestinal (IDC) and total (TDC) apparent digestibility coefficient of nutrients from cattle fed high-grain diets associated or not with technical cashew nut shell liquid (tCNSL) and two non-protein nitrogen (NPN) sources.

\begin{tabular}{|c|c|c|c|c|c|c|}
\hline \multirow{3}{*}{ Items } & \multicolumn{4}{|c|}{ Diets } & \multirow{3}{*}{ SEM } & \multirow{3}{*}{$\mathrm{P}<$} \\
\hline & \multicolumn{2}{|c|}{ - tCNSL } & \multicolumn{2}{|c|}{$+\mathrm{tCNSL}$} & & \\
\hline & $\mathrm{U}$ & SRU & $\mathrm{U}$ & SRU & & \\
\hline \multicolumn{7}{|c|}{ Dry matter } \\
\hline $\operatorname{RDC}\left(\mathrm{g} \mathrm{kg}^{-1}\right)$ & 437.55 & 424.10 & 399.87 & 431.65 & 1.793 & 0.50 \\
\hline IDC $\left(\mathrm{g} \mathrm{kg}^{-1}\right)$ & 533.58 & 537.73 & 547.78 & 529.70 & 2.619 & 0.97 \\
\hline TDC $\left(\mathrm{g} \mathrm{kg}^{-1}\right)$ & 738.92 & 733.70 & 728.75 & 732.55 & 1.550 & 0.98 \\
\hline \multicolumn{7}{|c|}{ Crude protein } \\
\hline $\operatorname{RDC}\left(\mathrm{g} \mathrm{kg}^{-1}\right)$ & 306.98 & 258.33 & 262.15 & 329.10 & 3.329 & 0.40 \\
\hline IDC $\left(\mathrm{g} \mathrm{kg}^{-1}\right)$ & 642.18 & 654.48 & 640.10 & 635.65 & 2.313 & 0.95 \\
\hline TDC $\left(\mathrm{g} \mathrm{kg}^{-1}\right)$ & 752.15 & 746.65 & 734.08 & 758.13 & 1.374 & 0.66 \\
\hline \multicolumn{7}{|c|}{ Neutral detergent fiber } \\
\hline $\operatorname{RDC}\left(\mathrm{g} \mathrm{kg}^{-1}\right)$ & 515.80 & 524.55 & 484.60 & 493.85 & 3.039 & 0.78 \\
\hline IDC $\left(\mathrm{g} \mathrm{kg}^{-1}\right)$ & 502.00 & 450.50 & 492.25 & 510.75 & 1.650 & 0.99 \\
\hline TDC $\left(\mathrm{g} \mathrm{kg}^{-1}\right)$ & 541.00 & 546.08 & 509.75 & 520.02 & 2.831 & 0.78 \\
\hline \multicolumn{7}{|c|}{ Ether extract } \\
\hline $\operatorname{RDC}\left(\mathrm{g} \mathrm{kg}^{-1}\right)$ & 320.38 & 309.48 & 263.18 & 298.48 & 5.542 & 0.90 \\
\hline IDC $\left(\mathrm{g} \mathrm{kg}^{-1}\right)$ & 690.42 & 660.55 & 721.15 & 714.80 & 4.143 & 0.73 \\
\hline $\operatorname{TDC}\left(\mathrm{g} \mathrm{kg}^{-1}\right)$ & 799.50 & 764.88 & 802.15 & 802.40 & 2.074 & 0.53 \\
\hline \multicolumn{7}{|c|}{ Starch } \\
\hline $\operatorname{RDC}\left(\mathrm{g} \mathrm{kg}^{-1}\right)$ & 579.68 & 541.63 & 599.93 & 553.18 & 6.579 & 0.93 \\
\hline IDC $\left(\mathrm{g} \mathrm{kg}^{-1}\right)$ & 713.98 & 732.95 & 692.05 & 719.78 & 5.447 & 0.96 \\
\hline TDC $\left(\mathrm{g} \mathrm{kg}^{-1}\right)$ & 889.95 & 883.73 & 886.85 & 880.90 & 1.378 & 0.97 \\
\hline \multicolumn{7}{|c|}{ Non-fibrous carbohydrates } \\
\hline $\operatorname{RDC}\left(\mathrm{g} \mathrm{kg}^{-1}\right)$ & 491.75 & 469.53 & 461.93 & 465.00 & 4.511 & 0.95 \\
\hline IDC $\left(\mathrm{g} \mathrm{kg}^{-1}\right)$ & 683.62 & 688.88 & 714.43 & 701.23 & 3.396 & 0.92 \\
\hline TDC $\left(\mathrm{g} \mathrm{kg}^{-1}\right)$ & 844.08 & 838.53 & 845.58 & 840.33 & 1.586 & 0.99 \\
\hline
\end{tabular}

SEM - standard error of mean, P - P value.

Azevedo et al. (2010) evaluated the inclusion of a low-quality hay and verified that it did not SRU in urea substitution in diets of steers feeding differ in relation to fiber degradation and ruminal 
fermentation of other nutrients probably due to the low efficiency of urea, which was confirmed in the present study (Table 4) and probably contributed to the responses $(\mathrm{P}>0.05)$ of the ruminal and intestinal apparent digestibility of NDF (Table 3 ).

When evaluating the methane mitigation produced by cattle fed CNSL, Shinkai et al. (2012) verified that the total digestibility of DM, $\mathrm{OM}, \mathrm{CP}$, and NDF decreased due to a reduction of a significant amount of bacteria, especially Butyrivibrio fibrisolvens. However, the tCNSL used in our study had a higher concentration of cardanol, cardol, and methylcardol, which did not present antimicrobial activity and, consequently, may have influenced the presented responses.

The apparent digestibility coefficients of the ethereal extract (EE) were also not influenced by the used additives. However, they provided responses superior to those recommended by Ítavo et al. (2002), who affirm that negative or near-zero ruminal digestion values of $\mathrm{EE}$ would be expected since there is no ruminal microorganism capable of using lipids as an energy source.

Table 4. Values of $\mathrm{pH}$ and ammoniacal nitrogen $\left(\mathrm{N}^{-\mathrm{NH}_{3}}\right)$ of rumen fluid, fecal and urinary nitrogen, plasma urea nitrogen (PUN) and microbial synthesis efficiency (SE) of cattle fed high-grain diets associated or not with technical cashew nut shell liquid (tCNSL) and two non-protein nitrogen (NPN) sources.

\begin{tabular}{|c|c|c|c|c|c|c|}
\hline \multirow{3}{*}{ Items } & \multicolumn{4}{|c|}{ Diets } & \multirow{3}{*}{ SEM } & \multirow{3}{*}{$\mathrm{P}<$} \\
\hline & \multicolumn{2}{|c|}{ - tCNSL } & \multicolumn{2}{|c|}{+ tCNSL } & & \\
\hline & $\mathrm{U}$ & SRU & $\mathrm{U}$ & SRU & & \\
\hline $\mathrm{pH}$ of rumen fluid & 6.51 & 6.36 & 6.43 & 6.44 & 0.057 & 0.31 \\
\hline $\mathrm{N}-\mathrm{NN}_{3}$ of rumen fluid $\left(\mathrm{mg} \mathrm{dL}^{-1}\right)$ & 14.24 & 13.35 & 15.16 & 13.45 & 1.481 & 0.81 \\
\hline $\mathrm{N}$ of feces $\left(\mathrm{g} \mathrm{d}^{-1}\right)$ & 47.09 & 50.61 & 52.76 & 46.64 & 3.166 & 0.50 \\
\hline $\mathrm{N}$ of urine $\left(\mathrm{g} \mathrm{d}^{-1}\right)$ & 85.12 & 90.94 & 91.23 & 86.58 & 6.272 & 0.87 \\
\hline PUN (mg dL-1) & 14.52 & 13.97 & 15.63 & 14.31 & 1.094 & 0.74 \\
\hline SE (g microbial $\mathrm{N} \mathrm{kg}^{-1}$ DOMR $)^{1}$ & 25.81 & 26.39 & 24.69 & 24.77 & 3.379 & 0.98 \\
\hline
\end{tabular}

SEM - standard error of mean, $\mathrm{P}$ - P value. ${ }^{1} \mathrm{~g}$ microbial $\mathrm{N} \mathrm{kg}^{-1}$ of DOMR - grams of microbial nitrogen per kg of degraded organic matter in rumen.

Because non-fibrous carbohydrates (NCF) were calculated from CP, NDF, EE, and mineral matter content of the dietary constituents and digesta of animals (SNIFFEN et al., 1992), they were also not influenced by diets.

Because the diets were isoproteic, isoenergetic (Table 1), and showed no variation in relation to the ruminal, intestinal, and total coefficients digestibility of nutrients, the TDN was also not influenced by diets supplied to the cattle.

Diets with high soluble carbohydrates are associated with a higher total acid production, as well as with an increased lactic acid production and, consequently, low ruminal $\mathrm{pH}$ values. The decrease in the $\mathrm{pH}$ of rumen can negatively influence DM intake, ruminal motility, fibrous fraction degradation, and microbial production, influencing the functioning of the rumen and, consequently, animal health (VAN SOEST, 1994).

The average values of $\mathrm{pH}$, ammoniacal nitrogen $\left(\mathrm{N}-\mathrm{NH}_{3}\right)$, and plasma urea nitrogen $(\mathrm{PUN})$ were not influenced by the used diets $(\mathrm{P}>0.05)$ (Table 4). Therefore, it is suggested a low efficiency in the protection of SRU, corroborating with Azevedo et al. (2010).

The $\mathrm{pH}$ values were maintained above the 6.2 considered by Van Soest (1994), as a minimum limit for an adequate fiber fermentation to not 
harm cellulolytic microorganisms, but lower than those verified by Castañeda et al. (2009), who used different NPN sources in the ruminant diet.

The ruminal $\mathrm{pH}$ values over time indicate that the lowest $\mathrm{pH}$ values were found close to 4 hours after the first feeding (Figure 1), which was expected due to the maximum digestion of the fed diet.

For $\mathrm{N}-\mathrm{NH}_{3}$ concentrations, all diets provided average values higher than $5 \mathrm{mg} \mathrm{dL}^{-1}$ (Table 4), which is considered by the literature to be the minimum for adequate ruminal fermentation. The highest $\mathrm{N}-\mathrm{NH}_{3}$ values were found two hours after the first feeding (Figure 1). These data confirm the large degradation of proteins, peptides, amino acids, and other nitrogenous substances that promote the release of ammonia into rumen fluid two hours after feeding.

Watanabe et al. (2010) reported a reduction in the in vitro $\mathrm{N}-\mathrm{NH}_{3}$ synthesis in diets containing CNSL. According to the authors, CNSL can inhibit the growth of proteolytic bacteria and reduce the adhesion and colonization capacity of these bacteria to their substrates. However, as discussed earlier, tCNSL may not have influenced the responses of the variables in Table 4 due to the characteristic of its composition since it did not present significant amounts of anacardic acid, which is the antimicrobial agent responsible for altering the ruminal microflora and, consequently, the verified answers.

Figure 1. Mean values and regression equations of $\mathrm{pH}$ and ammoniacal nitrogen (N-NH3) from rumen fluid of cattle according to the hours after feeding.

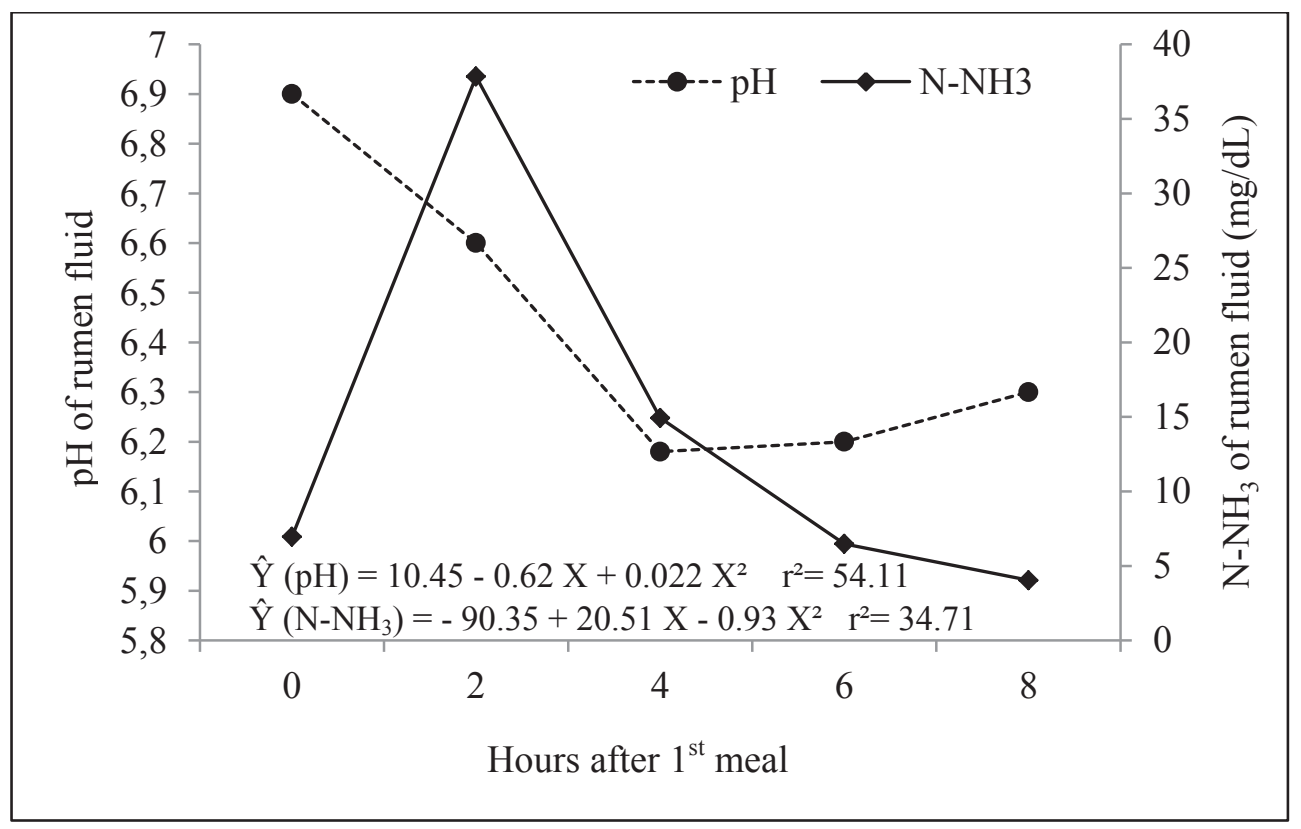

Taylor-Edwards et al. (2009) and Gardinal et al. (2016) evaluated the effect of urea and SRU on the digesta of steers fed a diet with approximately $40 \%$ NDF and verified that NPN sources did not influence rumen $\mathrm{pH}$ values, being close to 6.5 and 6.42 , respectively. However, the animals that fed
SRU had lower $\mathrm{N}-\mathrm{NH}_{3}$ concentrations in the rumen fluid in both cases when compared to the use of urea.

The optimal N-NH$H_{3}$ level varies according to the feed and availability of fermentable carbohydrates in the rumen. However, it is expected that the availability of $\mathrm{N}^{-\mathrm{NH}_{3}}$ from NPN sources may be 
more limiting for animals with high ruminal $\mathrm{N}$ requirements, such as those with a high intake or production demands or those that consume highly degradable feeds when compared to animals that require less $\mathrm{N}$ ruminal (TAYLOR-EDWARDS et al., 2009).

For Castillejos et al. (2007), many functional oils reduce the number of ammonia-producing bacteria, the rate of amino acid deamination, and hence the rate of ammonia production, thus increasing the amount of $\mathrm{N}$ that reaches the intestine. Thus, we expected that the animals fed tCNSL would obtain higher values of PUN, but it was not verified in Table 4.

Because the NPN and tCNSL sources may decrease deamination of the dietary protein in the rumen, favoring the efficiency of microbial synthesis, we expected that diets would influence the efficiency of synthesis. However, as the evaluated diets did not influence CP digestibility (Table 2) and $\mathrm{N}-\mathrm{NH}_{3}$ concentration in the rumen fluid, this favored the responses verified in Table $4(\mathrm{P}>0.05)$.

Some of the literature presented here refers to in vitro results of the use of functional oils in ruminant diets and it seems difficult to find an equivalence of them for in vivo assays due to the various effects that may be associated with the use of products with animals, such as breed, feed intake, physiological condition, as well as the effects related to the characteristics of the raw material at the time of extracting the plant extracts, requiring further researches concerning the supply of tCNSL.

\section{Conclusions}

Technical cashew nut shell liquid associated with non-protein nitrogen sources do not influence nutrient digestibility, ruminal fermentation, rumen microbial protein synthesis, and plasma urea nitrogen in cattle fed high-grain diets.

\section{References}

ASSOCIATION OF OFFICIAL ANALYTICAL CHEMISTRY - AOAC. Official methods of analysis. $15^{\text {th }}$ ed. Washington: AOAC International, 1990.

AZEVEDO, E. B.; PATIÑO, H. O.; SILVEIRA, A. L. F.; LÓPEZ, J.; NÖRNBERG, J. L.; BRÜNING, G. Suplementação nitrogenada com ureia comum ou encapsulada sobre parâmetros ruminais de novilhos alimentados com feno de baixa qualidade. Ciência Rural, Santa Maria, v. 40, n. 3, p. 622-627, 2010.

BAYAT, A. R.; TAPIO, I.; VILKKI, J.; SHINGFIELD, K. J.; LESKINEN, H. Plant oil supplements reduce methane emissions and improve milk fatty acid composition in dairy cows fed grass silage-based diets without affecting milk yield. Journal of Dairy Science, Champaign, v. 101, n. 2, p. 1136-1151, 2018.

BOURG, B. M.; TEDESCHI, L. O.; WICKERSHAM, T. A.; TRICARICO, J. M. Effects of slow-release urea product on performance, carcass characteristics, and nitrogen balance of steers fed steam-flaked corn. Journal of Animal Science, Champaign, v. 90, n. 11, p. 39143923, 2012.

BRANCO, A. F.; GIALLONGO, F.; FREDERICK, T.; WEEKS, H.; OH, J.; HRISTOV, A. N. Effect of technical cashew nut shell liquid on rumen methane emission and lactation performance of dairy cows. Journal of Dairy Science, Champaign, v. 98, n. 6, p. 4030-4040, 2015.

CASTAÑEDA, R. D. S.; BRANCO, A. F.; CONEGLIAN, S. M.; BARRETO, J. C.; GRANZOTTO, F.; TEIXEIRA, S. Substituição de ureia por cloreto de amônio em dietas de bovinos: digestibilidade, síntese de proteína microbiana, parâmetros ruminais e sanguíneos. Acta Scientiarum. Animal Sciences, Maringá, v. 31, n. 3, p. 271-277, 2009.

CASTILLEJOS, L.; CALSAMIGLIA, S.; FERRET, A.; LOSA, R. Effects of dose and adaptation time of a specific blend of essential oil compound on rumen fermentation. Animal Feed Science and Technology, Amsterdam, v. 132, n. 3-4, p. 186-201, 2007.

CECAVA, M. J.; MERCHEN, N. R.; GAY L, C.; BERGER, L. L. Composition of ruminal bacteria harvested from steers as influenced by dietary energy level, feeding frequency, and isolation techniques. Journal of Dairy Science, Champaign, v. 73, n. 9, p. 2480-2488, 1990.

COUTINHO, D. A.; BRANCO, A. F.; SANTOS, G. T. dos; OSMARI, M. P.; TEODORO, A. L.; DIAZ, T. G. Intake, digestibility of nutrients, milk production and composition in dairy cows fed on diets containing cashew 
nut shell liquid. Acta Scientiarum. Animal Sciences, Maringá, v. 36, n. 3, p. 311-316, 2014.

FENNER, H. Methods for determining total volatile base in rumen fluid by steam distillation. Journal of Dairy Science, Champaign, v. 48, n. 3, p. 249-251, 1965.

FERREIRA, M. A.; VALADARES FILHO, S. C.; MARCONDES, M. I.; PAIXÃO, M. L.; PAULINO, M. F.; VALADARES, R. F. D. Avaliação de indicadores em estudos com ruminantes: digestibilidade. Revista Brasileira de Zootecnia, Viçosa, MG, v. 38, n. 8, p. 15681573, 2009.

GARDINAL, R.; GANDRA, J. R.; CALOMENI, G. D.; VENDRAMINI, T. H. A.; TAKIYA, C. S.; FREITAS JUNIOR, J. E.; SOUZA, H. N.; RENNÓ, F. P. Effects of polymer coated slow-release urea on fermentation and nutrient total tract digestion of beef steers. Revista Brasileira de Zootecnia, Viçosa, MG, v. 45, n. 2, p. 63$70,2016$.

INSTITUTO ADOLFO LUTZ - IAL. Métodos físicoquímicos para análise de alimentos. $4^{\text {th }}$ ed. São Paulo: Instituto Adolfo Lutz, 2008. 1020 p.

ÍTAVO, L. C. V.; VALADARES FILHO, S. C.; SILVA, F. F.; VALADARES, R. F. D.; LEÃO, M. I.; CECON, P. R.; ÍTAVO, C. C. B. F.; MORAES, E. H. B. K.; PAULINO, P. V. R. Consumo e digestibilidade aparentes totais e parciais de nutrientes em novilhos alimentados com dietas contendo vários níveis de concentrado. Revista Brasileira de Zootecnia, Viçosa, MG, v. 31, n. 3, p. 1543-1552, 2002.

MAEDA, E. M.; ZEOULA, L. M.; GERON, L. J. V.; BEST, J.; PRADO, I. N.; MARTINS, E. N.; KAZAMA, R. Digestibilidade e características ruminais de dietas com diferentes níveis de concentrado para bubalinos e bovinos. Revista Brasileira de Zootecnia, Viçosa, MG, v. 36, n. 3, p. 716-726, 2007.

MYERS, W. D.; LUDDEN, P. A.; NAYIGIHUGU, V.; HESS, B. W. Technical note: a procedure for the preparation and quantitative analysis of samples for titanium dioxide. Journal of Animal Science, Champaign, v. 82, n. 1, p. 179-183, 2004.

NATIONAL RESEARCH COUNCIL - NRC. Nutrient requeriments of dairy cattle. $7^{\text {th }}$ rev. ed. Washington: National Academy Press, NAP, 2001. 381 p.

PUREVJAV, T.; HOFFMAN, M. P.; ISHDORJ, A.; CONOVER, A. J.; JEDLICKA, M. E.; PRUSA, K.;
TORRENT, J.; PUSILLO, G. M. Effects of functional oils and monensin on cattle finishing programs. The Professional Animal Scientist, Champaign, v. 29, n. 4, p. 426-434, 2013.

SHINKAI, T.; ENISHI, O.; MITSUMORI, M.; HIQUCHI, K.; KOBAYASHI, Y.; TAKENAKA, A.; NAGASHIMA, K.; MOCHIZUKI, M.; KOBAYASHI, Y. Mitigation of methane production from cattle by feeding cashew nut shell liquid. Journal of Dairy Science, Champaign, v. 95, n. 9, p. 5308-5316, 2012.

SNIFFEN, C. J.; O'CONNOR, J. D.; VAN SOEST, P. J.; FOX, D. G.; RUSSELL, J. B. A net carbohydrate and protein system for evaluating cattle diets. II. Carbohydrate and protein availability. Journal of Animal Science, Champaign, v. 70, n. 11, p. 3562-3577, 1992.

TAYLOR-EDWARDS, C. C.; HIBBARD, G.; KITTS, S. E.; MCLEOD, K. R.; AXE, D. E.; VANZANT, E. S.; KRISTENSEN, N. B.; HARMON, D. L. Effects of slowrelease urea on animal digesta characteristics and growth performance in beef steers. Journal of Animal Science, Champaign, v. 87, n. 1, p. 200-208, 2009.

USHIDA, K.; LASSALAS, B.; JOUANY, J. P. Determination of assay parameters for RNA analysis in bacterial and duodenal samples by spectrophotometry: influence of sample treatment and preservation. Reproduction Nutrition Development, Cambridge, v. 25, n. 6, p. 1037-1046, 1985.

VAN SOEST, P. J. Nutritional ecology of the ruminant. $2^{\text {th }}$ ed. Ithaca: Cornell, 1994. 476 p.

VAN SOEST, P. J.; ROBERTSON, J. B.; LEWIS, B. A. Symposium: carbohydrate methodology, metabolism, and nutritional implications in dairy cattle. Journal of Dairy Science, Champaign, v. 74, n. 10, p. 3583-3597, 1991.

WALDRIP, H. M.; TODD, R. W.; COLE, N. A. Prediction of nitrogen by beef cattle: a meta-analysis. Journal of Animal Science, Champaign, v. 91, n. 9, p. 4290-4302, 2013.

WATANABE, Y.; SUZUKI, R.; KOIKE, S.; NAGASHIMA, K.; MOCHIZUKI, M.; FORSTER, R. J.; KOBAYASHI, Y. In vitro evaluation of cashew nut shell liquid as a methane-inhibiting and propionateenhancing agent for ruminants. Journal of Dairy Science, Champaign, v. 93, n. 11, p. 5258-5267, 2010. 
